UDK $502.51(285)(497.4)$

$556.557(497.4)$

911.2:556](497.4)

DOI 10.21861/HGG.2016.78.02.05

\title{
The Spatial Development Potential of Škale and Velenje Lakes
}

\author{
Potencijal prostornoga razvoja \\ Škalskog i Velenjskog jezera
}

The research area is the strip of narrow lake land surrounding Velenje and Škale Lakes (in the Northeast Sub-alpine part of Slovenia) which has different potentials that provide opportunities for sustainable development.

The primary research goal was to create digital cartographic materials; current land use was displayed (updated in October, 2014 and February, 2015), and land use/land cover categories were created using GIS. An evaluation of the integrated assessment of the landscape's visual aesthetic qualities was also made, followed by a questionnaire survey.

Furthermore, the range of options to complement and improve existing proposals for the continued use of the lakes' banks, the direct hinterland of the lakes, and the surfaces of Škale and Velenje Lake, was established. Some ideas were in line with sustainable use - applying a natural concept, and some proposals were results of imaginative brainstorming. Finally, we proposed some spatial development scenarios for the area researched by the models.

Key words: sustainable planning, integrated landscape quality assessment, the scenario method, landscape region, Velenje Lake, Škale Lake, Slovenia
Istraživano područje dio je uskoga jezerskog područja Velenjskog i Skalskog jezera (sjeveroistočno subalpsko područje Slovenije) raznovrsnih potencijala koji omogućuju održiv razvoj.

Primarni je istraživački cilj bio načiniti digitalne kartografske materijale; prikazan je trenutačni način korištenja zemljišta (ažurirano u listopadu 2014. i veljači 2015.) te su s pomoću GIS-a oblikovane kategorije zemljišnoga pokrova i načina korištenja zemljišta. Zatim je provedena integrirana procjena vizualne i estetske kakvoće pejzaža, a nakon toga i anketno istraživanje.

Određen je raspon opcija za upotpunjavanje i poboljšanje postojećih prijedloga uporabe obale jezera, priobalnoga jezerskog pojasa te vodenih površina Skalskog i Velenjskog jezera. Neke su zamisli bile usklađene s održivim načinom korištenja - primjenom prirodnih koncepata, a neki su prijedlozi bili rezultat imaginativnoga brainstorminga. Naposljetku smo predložili scenarije prostornoga razvoja područja osmišljene prema modelima.

Ključne riječi: održivo planiranje, integrirana procjena kvalitete pejzaža, metoda scenarija, pejzaž, regija, Velenjsko jezero, Škalsko jezero, Slovenija 


\section{Introduction}

Regarding the lake water monitoring data (Šterbenk et al., 2015), the coal mining areas around both Velenje and Škale lakes present different potentials, which, from a developmental point of view, offer various opportunities for intelligent improvement, i.e. sustainable and thoughtful development. Regional development policies should be based on the inclusion of all stakeholders interested in the use of regional resources of the lakes' surroundings, as discussed in this paper. In addition to crucial user participation in the process of planning, there is the key role of decision makers and spatial planners, who must be aware of the limitations of the environment where the improvement project is being planned. Within this context it is extremely important not to succumb to the current "fashion", i.e. usually of those with short-term interests (equity, users, policy, etc.), rather to establish a long-term, thoughtful and sustainability-oriented development vision. Only in this way can we ensure that the quality, which has already been achieved by the existing subsidies allocated to the lake areas, can be sustainably maintained and developed.

The local authorities (the Velenje Municipality) established a project group with the main goal being the development of Škale lake lands as tourist destination. The Environmental Protection College (EPC) project subgroup was tasked with collecting land-use data for the research area. Additionally, we suggested carrying out a public survey, in order to adequately involve representatives of the interested public and users in the planning process (as required by the Aarhus Convention and other EU documents); we also invited other assorted visitors of the Velenje and Škale lake areas (Špeh and Furlan, 2015).

The purpose of the ongoing project was to prepare a set of options to complete and improve the existing land use and subsequent proposals for the use of the lake banks, the direct hinterland of the lakes, and water surface of both Škale and Velenje Lakes. Some ideas were in line with sustainable and applied natural concepts, but some proposals were the result of the aforementioned imaginative brainstorming.

\section{Uvod}

$\mathrm{Na}$ osnovi podataka o praćenju jezerske vode (Šterbenk i dr., 2015) pokazuje se da područje ugljenokopa na području Velenjskog i Škalskog jezera ima različite potencijale koji s razvojnoga motrišta nude brojne mogućnosti za pametno unaprjeđenje prostora, tj. održiv i promišljen razvoj. Mjere regionalnoga razvoja trebale bi se temeljiti na uključivanju svih dionika zainteresiranih za korištenje regionalnih resursa okolnoga jezerskog područja, kao što se i sagledava u ovom radu. Osim uključenosti korisnika u proces planiranja, ključnu ulogu imaju i donositelji odluka te prostorni planeri koji pri planiranju projekata unaprjeđenja moraju biti svjesni ograničenja okoliša. U tom je kontekstu iznimno važno ne podleći trenutačnom „pomodarstvu”, odnosno najčešće kratkoročnim interesima (primjerice vrijednosti zemljišta, interesima korisnika, politike itd.), nego uspostaviti dugoročnu, promišljenu razvojnu viziju usredotočenu na održivost. To je jedini način kojim ćemo omogućiti održivo upravljanje i razvoj kvalitete koja je već postignuta postojećim potporama dodijeljenima jezerskim područjima.

Lokalne vlasti (Općina Velenje) utemeljile su projektnu skupinu s ciljem razvoja Škalskog jezera kao turističkoga odredišta. Određena je projektna podskupina Visoke škole za zaštitu okoliša koja je trebala prikupiti podatke o korištenju zemljišta na istraživanom području. Usto smo preporučili i provođenje anketnoga istraživanja kako bismo u proces planiranja na odgovarajući način uključili predstavnike zainteresirane javnosti i korisnike (sukladno Aarhuškoj konvenciji i ostalim dokumentima EU). Uključili smo i druge posjetitelje Velenjskog i Škalskog jezera (Špeh i Furlan, 2015).

Svrha projekta bila je pripremiti nekoliko opcija za upotpunjavanje i poboljšanje postojećega načina korištenja zemljišta te potom prijedloge za korištenje jezerskih obala, neposrednoga priobalnog pojasa jezera te vodenih površina Škalskog i Velenjskog jezera. Neke od zamisli odgovarale su konceptu održivosti i primijenjenom prirodnom konceptu, no neki su prijedlozi proizašli iz imaginativnoga brainstorminga. 
The researched landscape resources have undergone a thorough makeover (especially in terms of land degradation and the devaluation of landscape resources), due to underground lignite excavation in the decades following the Second World War. On the other hand, new potential was seeded. Another landscape resource was uncovered - lakes - which should be treated as vulnerable water elements in spatial planning. According to this, the research was carried out in following steps:

1) Checking the actual state of landscape resources (mapping);

2) Determination of the attractiveness of the researched landscape;

3) Surveying of public opinion (potential users of the researched area included);

4) Analysis of the obtained data (survey answers and digitalisation of the mapped data);

5) Usage of the concept of scenarios in terms of (potential) development of the researched lake lands.

A cartographic presentation shows the existing land use (mapped in October, 2014 and updated in February, 2015). These data should help planners of future activities and different projects (infrastructure, services, offerings, etc.) for the area around both lakes. Locals, and those who were indirectly introduced into the region (via Google Earth and Street Map applications, for example), have recognised its spatial attractiveness. All concerned attributed high levels of landscape aesthetic quality to the lake lands.

\section{Methodology}

a) Inventory of the space - mapping, digitalisation of data, creating the database

The data for a terrain inventory of Velenje and Škale Lakes were gathered, for the purpose of having the most current information on land use at hand. The first mapping was conducted in October, 2014, and was later updated in February, 2015. At the beginning, knowledge of the existing state of
Zbog iskapanja podzemnih nalazišta lignita u desetljećima nakon Drugoga svjetskog rata istraživani pejzažni resursi doživjeli su temeljitu promjenu, posebice glede degradacije zemljišta i pada vrijednosti pejzažnih resursa. $S$ druge strane, otkriven je nov potencijal. Prepoznat je drugi pejzažni resurs - jezera, s kojima pri prostornom planiranju treba postupati kao s iznimno osjetljivim vodenim elementima. U skladu s time, istraživanje je provedeno u sljedećim koracima:

1) Provjera stvarnoga stanja pejzažnih resursa (kartiranje)

2) Utvrđivanje privlačnosti istraživanoga pejzaža

3) Istraživanje javnoga mnijenja u koje su uključeni potencijalni korisnici istraživanoga područja

4) Analiza dobivenih podataka (anketnih odgovora i digitalizacija kartiranih podataka)

5) Uporaba koncepta scenarija glede (potencijalnog) razvoja istraženoga jezerskog zemljišta.

Kartografski materijal prikazuje trenutačni način korištenja zemljišta (kartiranje je provedeno u listopadu 2014., a ažuriranje u veljači 2015.). Ti podaci pomoći će zaduženima za prostorno uređenje budućih aktivnosti i različitih projekata područja oko obaju jezera (infrastrukture, usluga, ponude itd.). Lokalni stanovnici i oni koji su neizravno upoznati s područjem (primjerice, preko Google Eartha i aplikacije Street Map) prepoznali su prostornu privlačnost razmatranoga područja i obje su spomenute skupine visoko ocijenile estetsku vrijednost jezerskoga područja.

\section{Metodologija}

a) Inventar prostora - kartiranje, digitalizacija podataka, izrada baze podataka

Podaci za terenski inventar Velenjskog i Škalskog jezera prikupljeni su kao najažurnije informacije o načinu korištenja zemljišta. Prvo kartiranje provedeno je u listopadu 2014., a podaci su ažurirani u veljači 2015. godine. Na početku je trebalo utvrditi postojeći način korištenja kako bi se mogle odrediti
The Spatial

Development Potential of Škale and Velenje Lakes

Potencijal prostornoga razvoja Škalskog $i$ Velenjskog jezera 
use was necessary for the identification and planning of further possibilities for spatial development and activities in the area researched. We designated the so-called mapping areas (zones), and the associated lake lands and the immediate hinterland of lakes were presented, accompanied by cartographic legends (land use categories). The results were given in digital form (maps), enabled by ArcGIS software. The program is compatible with the spatial databases used by the Velenje Municipality Spatial Office; maps were prepared as a useful supplement and tool for coordination with municipal spatial plans.

\section{b) Determining the attractiveness of the area}

EU regional policy legislation has put much importance on spatial planning - specifically connected to the attractiveness of the development aspect. The regulation is a part of the Territorial Agenda 2020 for Spatial Development (Europe 2020,2014), and the document Europe 2020, and is intended to synchronise and coordinate planning and the implementation of spatial interventions. The EU set out two new initiatives, namely, the Infrastructure for Spatial Information in the European Community (INSPIRE, 2007; INSPIRE, 2014), and the European Network on Spatial Development and Cohesion (ESPON, 2014), which are intended to provide the foundation for balanced, rational, inclusive and sustainable planning, and monitoring and management of spatial development in the EU and Europe in general.

While attending the course, Evaluation and Protection of the Geographical Environment, EPC students and the participants of the Summer School of the University of Oslo (UiO, 2014) learned about EU spatial guidelines on the basis of the impression and the perception of landscape characteristics of the studied lake area. Both groups of students completed an evaluation of the aesthetic quality of said landscape. We considered indicators of the attractiveness of the area: in Tab. 1 we evaluated the qualitative value of the lake area, and in Tab. 2 quantitative values were collected, which represent the perceptions of visitors of the researched area who were surveyed. i planirati daljnje mogućnosti prostornoga razvoja i aktivnosti na istraživanom području. Odredili smo tzv. područja kartiranja (zone) na kojima su prikazana povezana zemljišta jezera i njihovo priobalje, zajedno s kartografskim legendama (kategorije korištenja zemljišta). Rezultati su dani u digitalnom obliku (kao karte) korištenjem softvera ArcGIS. Program je kompatibilan s prostornim bazama podataka kakve rabi Ured za prostorno planiranje općine Velenje; karte su pripremljene kao korisna nadopuna i alat za usklađivanje s općinskim prostornim planovima.

\section{b) Utvrđivanje privlačnosti područja}

Propisi vezani uz regionalnu politiku Europske unije pridaju veliku važnost prostornom uređenju, posebno u vezi s privlačnošću dimenzije razvoja. Regulativa je dio dokumenta Teritorijalna agenda 2020 za prostorni razvoj (EUROPE 2020, 2014.) i dokumenta Europe 2020 kako bi sve prostorne intervencije bile usklađeno i sinkronizirano isplanirane i provedene. Europska unija pokrenula je dvije nove inicijative: Infrastrukturu prostornih podataka u Europskoj zajednici (INSPIRE, 2007; INSPIRE, 2014) i Europsku mrežu za prostorni razvoj i koheziju (ESPON, 2014) kako bi postavila temelje uravnoteženom, razumnom, uključivom i održivom planiranju, nadziranju i upravljanju prostornim razvojem u državama članicama EU-a i Europi općenito.

Pohađajući kolegij Vrednovanje i zaštita geografskog okoliša, studenti Visoke škole za zaštitu okoliša i sudionici Ljetne škole Sveučilišta u Oslu (2014.) upoznali su se s prostornim smjernicama Europske unije na temelju dojmova i percepcije pejzažnih značajka proučavanoga jezerskog područja. Obje skupine studenata provele su vrednovanje estetske kvalitete toga pejzaža. Razmotrili smo pokazatelje privlačnosti područja: u tab. 1 vrednovali smo kvalitativnu vrijednost jezerskoga područja, a u tab. 2 prikupljene su kvantitativne vrijednosti koje predstavljaju percepciju anketiranih posjetitelja proučavanoga područja. 


\section{c) Survey and data analysis}

Questionnaire is an appropriate method of determining the opinions, critiques and suggestions of interested groups. It brings out a great deal of important information that cannot be provided by statistics. A focused survey list was prepared, because we were interested in the assessment of (potential) users of the researched area. At the same time, we kept in mind the methodological shortcomings of the survey approach (subjectivity of respondents and interviewers), which is normally used when considering the socio-geographic situation.

There were 419 respondents included in the survey, which used the convenience sampling method. Respondents who were found in the researched area (October, 2015), and were willing to participate, were surveyed after hearing a short description of the project aims - meeting the needs of future users at the lake lands.

The questionnaire was formed according to the project goals. It was meant (in accordance with the Aarhus Convention) to include and inform the public, and give them the opportunity to assess, suggest, and take part in planning. Their opinions were especially important since they are, or will be, the users of the researched area. We started with general questions on their recreation habits (aim, frequency) regarding visiting the researched area, and then gave them the opportunity to assess its present state (landscape arrangement); we concluded by asking specific (personal) questions about their needs, wishes, and means (e.g. financial contribution to investment/events). Additionally, the questionnaire was tested for comprehensiveness and question complexity prior to the fieldwork survey.

\section{d) Scenarios/modelling}

The scenario method was used to aid in the perception of inventoried space. Students worked individually at first, and then prepared joint (project) proposals for spatial development that they perceived as possible offerings of Velenje and Škale lakes and the surrounding landscape. Ideas and

\section{c) Anketno istraživanje i analiza podataka}

Anketno istraživanje prikladna je metoda za utvrđivanje stavova, kritika i prijedloga zainteresiranih skupina. Ono omogućuje dobivanje velikog broja važnih informacija do kojih nije moguće doći uporabom statističkih podataka. Pripremljen je i fokusirani anketni popis jer nas je zanimala procjena (potencijalnih) korisnika razmatranoga područja. Istodobno smo bili svjesni metodoloških nedostataka anketnoga pristupa (subjektivnost ispitanika i anketara) koji se najčešće rabi pri proučavanju neke sociogeografske situacije.

Anketnim istraživanjem obuhvaćeno je 419 ispitanika, uz korištenje prigodnoga uzorka. Ispitanicima koji su se zatekli na istraživanom području (u listopadu 2015.) i bili su voljni sudjelovati prvo je izložen kratak opis ciljeva projekta o zadovoljavanju potreba budućih korisnika jezerskoga područja nakon čega je popunjen upitnik.

Upitnik je oblikovan prema projektnim ciljevima, a namjera mu je bila (u skladu s Aarhuškom konvencijom) uključiti javnost, informirati je i dati joj priliku da procijeni situaciju, osmisli prijedloge te sudjeluje u procesu planiranja. Mišljenje javnosti bilo je osobito važno jer se radilo o postojećim ili budućim korisnicima istraživanoga područja. Upitnik smo započeli općim pitanjima o njihovim navikama posjećivanja toga područja (ciljevima, učestalosti), nakon čega smo im dali priliku da procijene njegovo trenutačno uređenje, a zaključili smo s posebnim (osobnim) pitanjima o njihovim potrebama, željama i mogućnostima (primjerice, mogućnostima financijskoga ulaganja/doprinosa događajima). Prije provođenja ankete na terenu testirali smo upitnik, odnosno njegovu opsežnost i složenost pitanja.

\section{d) Scenariij/modeliranje}

Za pomoć u percepciji proučavanoga prostora korištena je metoda scenarija. Studenti su isprva samostalno radili, a zatim su pripremili zajedničke projektne prijedloge za prostorni razvoj sukladno svomu viđenju potencijalnih mogućnosti Velenjskog i Škalskog jezera te okolnoga pejzaža.
The Spatial

Development Potential of Škale and Velenje Lakes

Potencijal prostornoga razvoja Škalskog $i$ Velenjskog jezera 
HRVATSKI

GEOGRAFSKI

GLASNIK

78/2,121-142 (2016.) suggestions related to the content were based on different ideas; from sustainable, to commercial, as well as more imaginative - without regard to the limited resource capacity of the researched environment. Two simplified scenarios were formed for the landscape modelling and simulation of future developments, using knowledge of current land
Zamisli i prijedlozi povezani sa sadržajem imali su različite osnove - od održivih do komercijalnih, kao i onih naglašenije imaginativna karaktera, ne uzimajući u obzir ograničene kapacitete istraživanih okolišnih resursa. $\mathrm{Na}$ temelju znanja o trenutačnom načinu korištenja zemljišta i željenim budućim funkcijama pejzaža osmišljena su

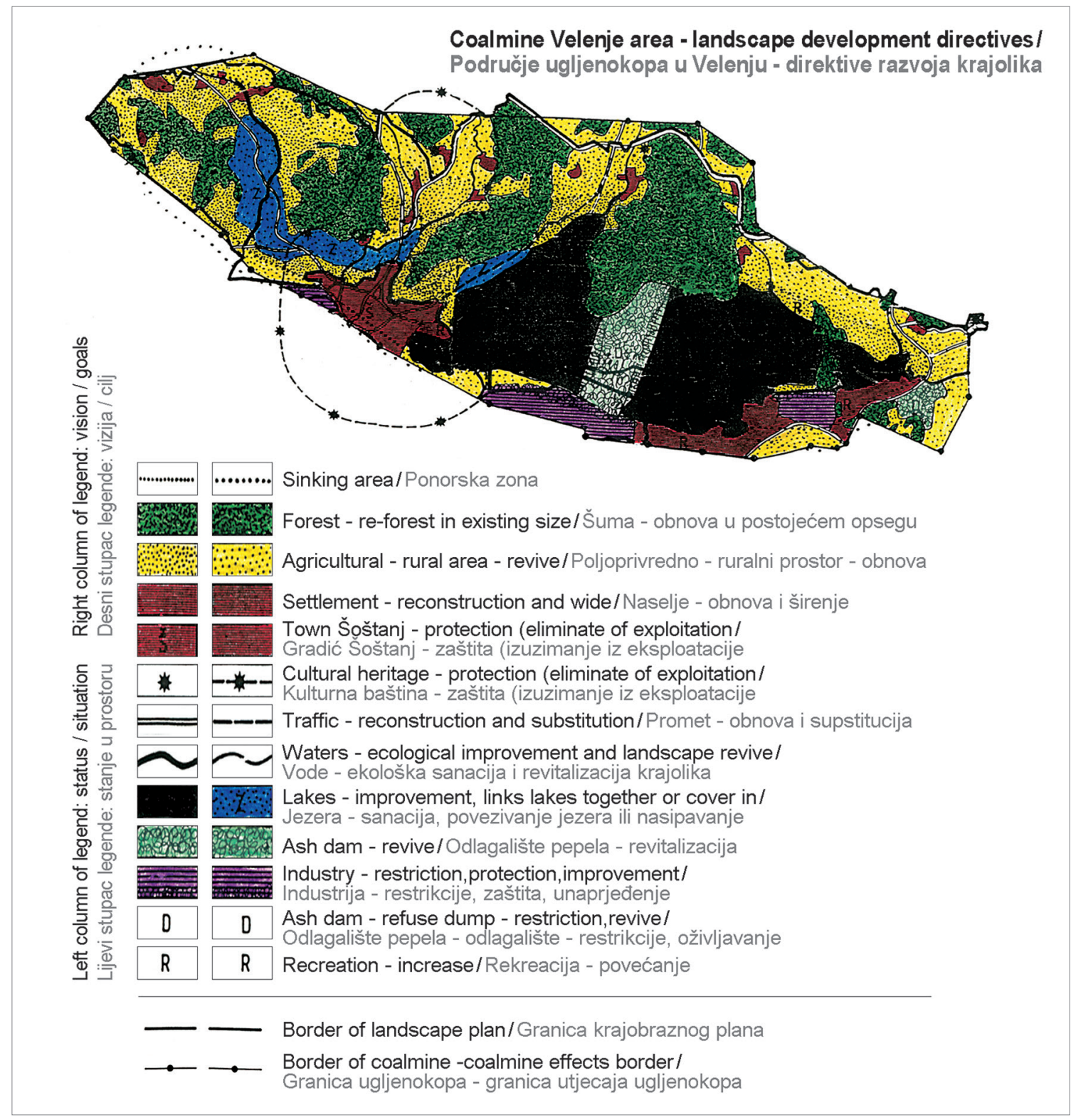

Fig. 1 Development model designed by the Institute for Urban Planning in Velenje SI. 1. Razvojni model osmišljen na Institutu za urbano planiranje u Velenju Source / lzvor: Zavod za urbanizem Velenje, 1990 
use and the desired future landscape function. The models were used for positioning activities in the area (zoning, land use), in accordance with previously established policy - intensive development, or sustainable development (of the area). Intensive development included the development of those activities which would enable economically efficient development, regardless of the consequences to the area. The Sustainable Development option primarily developed those activities that were not focused on profit. The comparison was largely based on development concepts, which, while not generally acceptable, was very instructive to students and presented the advantages and weaknesses of the individual concepts. The formation of spatial development scenarios/models was methodologically informative. Environmental capacity and the limit of landscape resources (water, soil, etc.) were not included as the data for biological and chemical parameters were not provided.

With these simple "student models", we set the basis for the production of new development models, which would be made in following planning steps. We would like to improve (and check and update) development models that were formed within the landscape designs of the subsidence area of Velenje Coal Mine in 1980s and 1990s at the Institute for Urban Planning in Velenje (Fig. 1) (Piano, 1994/1995; Zavod za urbanizem Velenje, 1988-1990).

\section{The area of research}

The area discussed in the paper is located in Šalek Valley, in the north-eastern part of Slovenia. It belongs to the Savinja statistical region, but its basic geomorphology, and tectonic, economic, and demographic characteristics have made it special even at the national level. One third of all Slovenian electricity is produced there. Though the underground excavation of lignite has degraded the region, it later enabled for new spatial potential to develop. The lakes' area (approx. $6 \mathrm{~km}^{2}$ ) introduced new development potentials in terms of tourism connected to culture and recent history. We researched only two lakes, because western edge dva jednostavna scenarija za oblikovanje pejzaža i simulaciju budućega razvoja. Ti su modeli iskorišteni za pozicioniranje aktivnosti u području (zoniranje, način korištenja zemljišta) sukladno prethodno određenim uvjetima - njegovu intenzivnom ili održivom razvoju. Intenzivni razvoj obuhvaćao je razvoj aktivnosti koje omogućuju ekonomski učinkovit razvoj neovisno o njegovu utjecaju na područje. Opcija Održivoga razvoja ponajprije je razvijala aktivnosti koje nisu bile usmjerene na profit. Usporedba je bila uglavnom temeljena na razvojnim konceptima što je, iako općenito nije prihvatljivo, bilo korisno za studente predstavljajući prednosti i nedostatke pojedinačnih koncepata. Oblikovanje scenarija/modela prostornoga razvoja bilo je informativno s metodološkoga gledišta. Kapacitet okoliša i ograničenja pejzažnih resursa (voda, tlo itd.) nisu uzeti u obzir jer podaci o biološkim i kemijskim parametrima nisu bili dostupni.

Pomoću tih jednostavnih „studentskih modela” postavili smo temelj izrade novih razvojnih modela koji trebaju biti provedeni u idućim koracima planiranja. Namjeravamo također unaprijediti (provjeriti $\mathrm{i}$ ažurirati) razvojne modele oblikovane u sklopu pejzažnoga planiranja područja subsidencije rudnika ugljena Velenje 1980-ih i 1990-ih godina na Institutu za urbano planiranje u Velenju (sl. 1.) (Piano, 1994/1995; Zavod za urbanizem Velenje, 1988-1990).

\section{Područje istraživanja}

Područje o kojem je u radu riječ nalazi se u Šaleškoj dolini, na sjeveroistoku Slovenije i pripada Savinjskoj statističkoj regiji, no njegove geomorfološke, tektonske, gospodarske i demografske značajke čine ga posebnim čak i na državnoj razini. Primjerice, trećina električne energije potrebne za opskrbu Slovenije proizvodi se upravo u tom dijelu zemlje. Podzemni iskop lignita isprva je uzrokovao degradaciju regije, no poslije je omogućio razvoj novih prostornih potencijala. Područje jezera (površine oko šest četvornih kilometara) omogućilo je nove razvojne potencijale $\mathrm{u}$ vidu turističke ponude povezane $s$ kulturom i nedavnom poviješću regije. Mi smo istražili samo dva jezera jer je okoliš jeze-
The Spatial

Development Potential of Škale and Velenje Lakes

Potencijal prostornoga razvoja Škalskog i Velenjskog jezera 
HRVATSKI GEOGRAFSKI GLASNIK

78/2,121-142 (2016.)

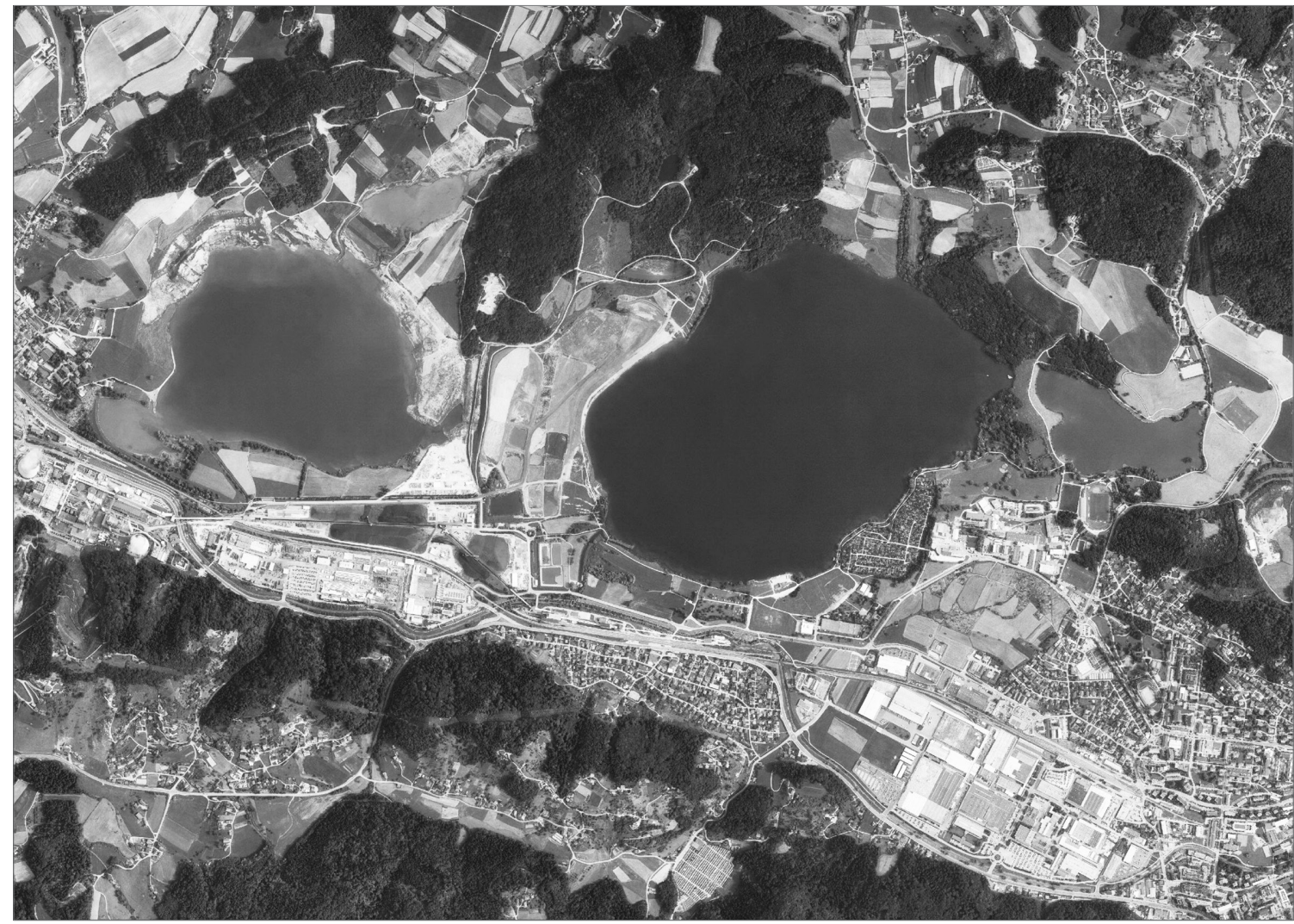

Fig. 2 The research area and land use in its surroundings

SI. 2. Područje istraživanja i način korištenja zemljišta u okolnom prostoru

Source / Izvor: Atlas okolja, 2015

of the lake area is completely unstable. Moreover, the underground lignite excavation is still in process.

Velenje Lake is the larger lake, in the central position (Fig. 2), while Škale Lake is the smaller. In the extreme left side of the area (photo) the underground excavation is still in process and also the left edge lake is still spreading (Družmirje Lake by the town of Šoštanj), whereas the lakes of Velenje and Škale are almost stable in area.

Consequently, very intensive anthropogenic land use (road and railway infrastructure, industrial zones, settlements) can be seen near the southern parts of the lakes, whereas the northern lake banks are covered with forest and agricultural land. ra na krajnjem zapadnom rubu izrazito nestabilan. Osim toga, podzemno iskapanje lignita još je uvijek u tijeku.

Središnji položaj ima veće Velenjsko jezero (sl. 2), dok je manje jezero Škalsko jezero. $\mathrm{Na}$ krajnjem lijevom dijelu prikazanoga područja još uvijek je u tijeku podzemno iskapanje lignita; lijevi rub jezera i dalje se širi (jezero Družmirje pokraj grada Šoštanja), dok je područje oko Velenjskog i Škalskog jezera gotovo stabilizirano.

Stoga je na južnim dijelovima jezera vidljivo vrlo intenzivno antropogeno korištenje prostora (cestovna i željeznička infrastruktura, industrijske zone, naselja), a sjeverne obale jezera prekrivene su šumama i poljoprivrednim zemljištem. 
Field work results

Rezultati terenskoga rada

Inventory of space: mapping, digitalisation of data, and creation of databases

The cartographic database was formed on the basis of the field inventory of land use for the banks of Velenje and Škale Lakes, using digital orthophoto (DOF) data.

The maps were made by using ArcGIS Spatial Analyst, which uses a wide range of spatial model-

\section{Inventar prostora - kartiranje, digitalizacija podataka i izrada baza podataka}

Kartografska baza podataka načinjena je na temelju terenskoga inventara načina korištenja zemljišta na obalama Velenjskog i Škalskog jezera te s pomoću digitalnih ortofoto-podataka.

Karte su načinjene uporabom ekstenzije ArcGIS Spatial Analyst, koja nudi široku paletu alata za

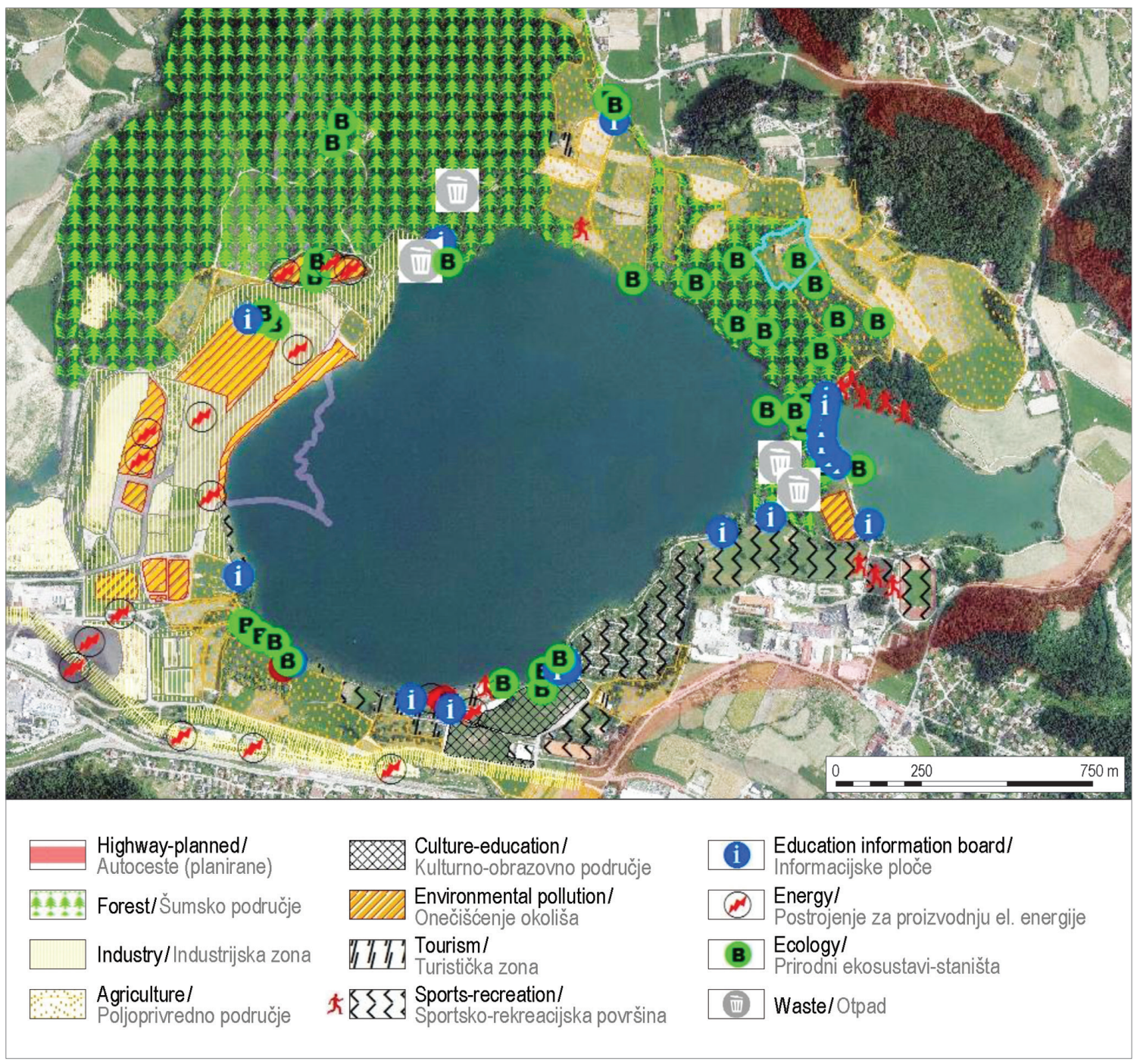

Fig. 3 Field inventory of Velenje Lake land use SI. 3. Iskorištenosti tla na Veleniskom jezeru Source / Izvor: Špeh and Furlan, 2015 
ing and analysis tools; including a method of interpolation, which can produce a raster of terrain data for measuring/observing sites.

\section{Integrated assessment of landscape visual aesthetic qualities}

Considering the landscape quality of the lake area, we used indicators of its attractiveness (Tab. 1). prostorno modeliranje i analizu, uključujući metodu interpolacije za dobivanje rasterskih podataka za mjerenje/promatranje terena.

\section{Integrirana procjena vizualne i estetske kakvoće pejzaža}

Uzimajući u obzir kakvoću pejzaža jezerskoga područja, upotrijebili smo pokazatelje njegove pri-

Tab. 1 Matrix for estimating the level of attractiveness of the landscape.

Tab. 1. Matrica za procjenu razine privlačnosti pejzaža

\begin{tabular}{|c|c|c|c|c|}
\hline \multirow{2}{*}{$\begin{array}{l}\text { Parameters / } \\
\text { Academic level }\end{array}$} & \multicolumn{4}{|c|}{$\begin{array}{l}\text { Assessment (in \%) / } \\
\text { Type of research question }\end{array}$} \\
\hline & 1 & 2 & 3 & 4 \\
\hline \multirow[t]{2}{*}{ Scale / Veličina } & Close / Vrlo Malena & Small / Malena & Big / Velika & Large / Vrlo Velika \\
\hline & 2.4 & - & 92.8 & 4.8 \\
\hline \multirow[t]{2}{*}{ Diversity / Raznovrsnost } & $\begin{array}{c}\text { Homogeneous / } \\
\text { Homogena }\end{array}$ & Simple / Jednostavna & Different / Drukčija & Complex / Složena \\
\hline & - & 25.6 & 62.8 & 11.6 \\
\hline \multirow[t]{2}{*}{ Harmony / Sklad } & Chaotic / Kaotičan & $\begin{array}{c}\text { Disharmonious / } \\
\text { Neskladan }\end{array}$ & $\begin{array}{l}\text { Balanced / } \\
\text { Uravnotežen }\end{array}$ & Harmonic / Sklad \\
\hline & - & 7.1 & 66.7 & 26.2 \\
\hline \multirow[t]{2}{*}{ Movement / Kretanje } & Violent / Silovito & $\begin{array}{l}\text { Non-Existent / } \\
\text { Nepostojeće }\end{array}$ & Lively / Živahno & Still / Statično \\
\hline & - & - & 28.6 & 71.4 \\
\hline \multirow[t]{2}{*}{ Colour / Boja } & $\begin{array}{l}\text { Monochromatic / } \\
\text { Jednobojna }\end{array}$ & Soft / Pastelna & Bright / Jarka & Colourful / Šarena \\
\hline & - & 16.6 & 42.9 & 40.5 \\
\hline \multirow[t]{2}{*}{ Smell / Miris } & $\begin{array}{c}\text { Unpleasant / } \\
\text { Neugodan }\end{array}$ & $\begin{array}{c}\text { Importunate / } \\
\text { Nesnosan }\end{array}$ & Neutral / Neutralan & Pleasant / Ugodan \\
\hline & 15.9 & 11.4 & 61.3 & 11.4 \\
\hline \multirow[t]{2}{*}{ Sound / Zvuk } & $\begin{array}{c}\text { Importunate / } \\
\text { Nesnosan }\end{array}$ & $\begin{array}{l}\text { Troublesome / } \\
\text { Problematičan }\end{array}$ & Still / Tih & Pleasant / Ugodan \\
\hline & - & - & 67.4 & 32.6 \\
\hline \multirow[t]{2}{*}{ Impression / Dojam } & $\begin{array}{l}\text { Depressing / } \\
\text { Depresivan }\end{array}$ & $\begin{array}{l}\text { Unpleasant / } \\
\text { Neugodan }\end{array}$ & Pleasant / Ugodan & Beautiful / Lijep \\
\hline & - & 2.4 & 67.4 & 30.2 \\
\hline \multirow[t]{2}{*}{ Emotion / Osjećaj } & Imminent / Prijeteći & Unsafe / Nesiguran & Safe / Siguran & Pleasant / Ugodan \\
\hline & - & - & 34.9 & 65.1 \\
\hline \multirow[t]{2}{*}{ Expression / Pojavnost } & $\begin{array}{l}\text { Uninteresting / } \\
\text { Nezanimljiva } \\
\end{array}$ & Quiet / Spokojna & $\begin{array}{l}\text { Interesting / } \\
\text { Zanimljiva }\end{array}$ & Exciting / Uzbudljiva \\
\hline & 2.5 & 19 & 59.5 & 19 \\
\hline \multirow[t]{2}{*}{ Uniqueness / Jedinstvenost } & Usual / Uobičajena & Unusual / Neobična & Rare / Rijetka & Unique / Jedinstvena \\
\hline & 27.9 & 13.9 & 34.9 & 23.3 \\
\hline
\end{tabular}

Source / Izvor: Kliucininkas, 2008 
We evaluated the qualitative value of the lakeside area and collected data using quantitative values, which represent the perception of random respondents in the researched area (Tab. 2). The evaluators (visitors) were students from both high school institutions involved (visitors - EPC in 2013 and 2014/ $\mathrm{UiO}$ in 2014) in the research, not burdened by local perspective.

The first contact with the researched area and its initial impression on visitors were generally positive and enjoyable. The lakeside area was mostly seen as "large" scale (92.8\%) and "diversified" (62.8\%). In addition to the diversity of the researched space, respondents had the impression of a "balanced" (66.7\%) and "peaceful" area (71.4\%). While the indicator colour was defined as "bright" (42.9\%) and "colourful" (40.5\%), the smell of the lake area was mostly described as neutral (61.3\%) even the noise was not perceived as disturbing. As far as opinions regarding the uniqueness of the observed lake lands, the respondents were of differing opinions: $27.9 \%$ of visitors considered the lake area to be "usual" landscape; $13.9 \%$ of the respondents defined it as "unusual"; $34.9 \%$ of them specified the land to be "rare"; and $23.3 \%$ of respondents chose the "unique" option.

Afterwards, the lake area was also evaluated using a synthesis assessment to determine the level of aesthetic quality. The respondents (visitors, EPC students) estimated the landscape to be of "high quality" in almost half of the cases (48.9\%) in 2013, as opposed to $41.5 \%$ in 2014 (when $\mathrm{UiO}$ students vlačnosti (tab. 1). Procijenili smo kvalitativnu vrijednost jezerskoga područja i prikupili podatke $s$ pomoću kvantitativnih vrijednosti koje predstavljaju viđenje proučavanoga područja od strane nasumično odabranih i ispitanih posjetitelja (tab. 2). Procjenitelji, odnosno posjetitelji bili su studenti obaju visokoškolskih obrazovnih ustanova (posjetitelji - studenti Visoke škole za zaštitu okoliša 2013./2014. te Sveučilišta u Oslu 2014.) uključenih u istraživanje, ali neopterećen lokalnom perspektivom.

Prvi kontakt s istraživanim područjem i dojmovi koje je ostavilo na posjetitelje bili su općenito pozitivni i ugodni. Jezersko područje uglavnom je doživljeno kao veliko $(92,8 \%)$ i raznoliko $(62,8 \%)$. Osim raznovrsnosti istraživanoga područja, posjetitelji su također stekli dojam njegove uravnoteženosti $(66,7 \%)$ i spokoja $(71,4 \%)$. Dok je pokazatelj boje definiran jarkim (42,9\%) i šarolikim (40,5\%), miris jezerskoga područja uglavnom je opisivan kao neutralan (61,3\%), a ni buka nije doživljena kao smetnja. Kad je riječ o njihovu mišljenju o jedinstvenosti promatranoga jezerskog područja, ispitanici nisu bili tako složni - 27,9 \% posjetitelja smatralo je jezersko područje uobičajenim pejzažom, $13,9 \%$ definiralo ga je neobičnim, 34,9\% opisalo ga je kao rijetko, a 23,3\% kao jedinstveno.

Idući je korak bila evaluacija jezerskoga područja s pomoću sintetske procjene kako bi se utvrdila razina estetske kakvoće. Gotovo polovica ispitanika (posjetitelji, studenti Visoke škole za zaštitu okoliša) ocijenila je 2013. godine pejzaž kao visokokvalitetan (njih 48,9 $\%$ ), no taj je postotak 2014. pao na 41,5\% (kada su se
The Spatial

Development Potential of Škale and Velenje Lakes

Potencijal prostornoga razvoja Škalskog $i$ Velenjskog jezera

Tab. 2 Quantitative indicators of urban landscape quality.

Tab. 2. Kvantitativni pokazatelji kakvoće urbanoga pejzaža

\begin{tabular}{|c|c|c|c|}
\hline $\begin{array}{c}\text { Levels of landscape quality (in scale of micro areas) } \\
\text { / Razine kakvoće pejzaža (u mjerilu mikropodručja) }\end{array}$ & $\begin{array}{c}\text { Points / } \\
\text { Bodovi }\end{array}$ & $\mathbf{2 0 1 3}$ (\%) & $\mathbf{2 0 1 4}$ (\%) \\
\hline Very high / Vrlo visoka & $>34$ & 22.2 & 29.3 \\
\hline High / Visoka & $30-34$ & 48.9 & 29.3 \\
\hline Medium / Srednja & $26-29$ & 24.4 & 0 \\
\hline Low / Niska & $21-25$ & 4.4 & 0 \\
\hline Very low / Vrlo niska & $<25$ & 0 & \\
\hline
\end{tabular}

Source / Izvor: Kliucininkas, 2008 
joined the research). In contrast, the percentage of answers for the category of "very high" increased by $7.1 \%$, and for the category of "medium" landscape quality by $4.9 \%$. There were no "low" quality ratings in 2014.

\section{The survey}

The data from 419 questionnaires were analysed. The questionnaires consisted of 15 open and closed type questions. The findings were as follows: $17.80 \%$ of the respondents were men and $15.27 \%$ were women, in the age range of $15-$ 25 . We consider these data to be important since these respondents are potential future users of the researched area. Furthermore, we documented the origins of the respondents: $63 \%$ were locals; the rest $(37 \%)$ came from elsewhere. We checked if visitors preferred one lake over the other. $79 \%$ of respondents visited both lakes and found the whole lake region interesting. Both lakes offer different scenery and people wanted to enjoy the aesthetic qualities of both.

We aimed to find out how often visitors came to the lake area of Škale and Velenje lake (Tab. 3). A1most half of the visitors (47\%) visited Velenje Lake once a month, meanwhile Škale Lake is visited with the same frequency by $39 \%$ respondents. There was a smaller difference concerning the other categories: once, twice, and multiple times per week. A small number (6\%) of respondents visited Škale Lake every day, and only $2 \%$ visited Velenje Lake istraživanju pridružili i studenti Sveučilišta u Oslu). S druge strane, postotak odgovora u kategoriji „vrlo visoka" 2014. bio je veći za 7,1 \%, odnosno 4,9 \% u kategoriji „srednja kakvoća pejzaža”. Te godine kakvoću pejzaža nitko nije ocijenio kao „vrlo nisku”.

\section{Anketa}

Analizirani su podaci 419 ispunjenih upitnika sastavljenih od 15 pitanja otvorenoga i zatvorenoga tipa, a rezultati su bili sljedeći: u dobnoj skupini od 15 do 25 godina $17,8 \%$ anketiranih bili su muškarci, a 15,27 \% žene. Te smo podatke smatrali važnima jer je riječ o ispitanicima koji bi mogli biti potencijalni korisnici istraživanoga područja u budućnosti. Nadalje, utvrđeno je da $63 \%$ ispitanika čine lokalni stanovnici, a preostalih $37 \%$ došlo je s nekoga drugog područja. Također je ispitano preferiraju li posjetitelji jedno jezersko područje u odnosu na drugo. Njih $79 \%$ posjetilo je oba jezera i reklo da cijelo jezersko područje smatraju zanimljivim. Jezera imaju različite krajolike, a posjetitelji žele uživati u estetskoj kakvoći i jednoga i drugoga.

Namjera nam je bila i saznati koliko često posjetitelji dolaze u područje oko Škalskog i Velenjskog jezera (tab. 3). Gotovo polovica posjetitelja (47 \%) posjećivala je Velenjsko jezero jednom mjesečno, dok je Škalsko jezero istom učestalošću posjećivalo njih $39 \%$. Ta je razlika bila manja za ostale kategorije - jednom do dvaput tjedno i nekoliko puta tjedno. Svaki je dan na Skalsko jezero dolazilo $6 \%$ ispitanika, a na Velenjsko jezero samo $2 \%$ ispitanika. Je-

Tab. 3 Visitor frequency for Škale and Velenje Lakes.

Tab. 3. Učestalost posjeta Škalskom i Velenjskom jezeru

\begin{tabular}{|c|c|c|}
\hline Frequency / Učestalost & Škale Lake / Škalsko jezero & Velenje Lake / Velenjsko jezero \\
\hline Once per month / Jednom na mjesec & $39 \%$ & $47 \%$ \\
\hline Once per week / Jednom na tjedan & $21 \%$ & $19 \%$ \\
\hline Twice per week / Dvaput na tjedan & $14 \%$ & $14 \%$ \\
\hline Several times per week / Nekoliko puta na tjedan & $20 \%$ & $18 \%$ \\
\hline Every day / Svaki dan & $6 \%$ & $2 \%$ \\
\hline
\end{tabular}

Source / Izvor: Špeh and Furlan, 2015 
every day. This could be due to the lake's size, as it takes longer to see Velenje Lake (approx. $8 \mathrm{~km}$ in circumference). Škale Lake is smaller and easier to see quickly (approx. $2 \mathrm{~km}$ in circumference).

After this, we continued exploring more specific themes. One aim was to categorise visitors according to their interests and desired activities, for the purposes of future spatial development of the area. We also checked their level of willingness to pay for recreation.

\section{a) The most important conditions and available leisure activities and events.}

Fig. 4 shows that visitors prefer events offered based on their attractiveness. They were asked to evaluate five categories (free parking, attractive event, entrance fee, ability to purchase tickets online, and the cultural-education offering) with values ranging from 1 to 5 with value 1 representing the most important.

Almost 27\% of respondents chose the highest value (1) for the category of attraction. The free parking was the second most frequently chosen option (21\%). The entrance fee and the ability to purchase tickets online combined were the third most important indicator (26\%). The least importance was attributed to the cultural and education themes as offered at the event; $27.45 \%$ of respondents chose the lowest value (5). dan od razloga tomu mogla bi biti i veličina jezera jer je opseg Velenjskog jezera veći (približno osam kilometara), dok je Škalsko jezero manje (oko dva kilometra u opsegu) te je njegov obilazak brži.

Istraživanje je nastavljeno specifičnijim temama, a jedan od ciljeva bio je kategorizirati posjetitelje prema njihovim interesima i željenim aktivnostima za buduće prostorno uređenje područja. Ispitali smo i njihovu spremnost za plaćanje rekreacije.

\section{a) Najvažniji uvjeti i dostupne rekreativne aktivnosti i događaji}

S1. 4. pokazuje da posjetitelji preferiraju ponuđene događaje na temelju njihove atraktivnosti. Posjetitelji su trebali ocijeniti pet kategorija (besplatno parkiranje, privlačno događanje, cijenu ulaznice, mogućnost kupnje ulaznice internetom i kulturno-obrazovnu ponudu) vrijednostima u rasponu od 1 do 5 , s time da je vrijednost 1 označavala najveću važnost.

Gotovo $27 \%$ ispitanika najvišu vrijednost (1) dodijelilo je kategoriji privlačnosti. Cijena ulaznice bila je druga najčešće birana opcija (21 \%), a besplatno parkiranje i mogućnost kupnje ulaznice internetom treći najvažniji pokazatelj (26\%). Najmanju važnost ispitanici su dodijelili kulturnim i obrazovnim temama ponuđenima na događaju; $27,45 \%$ ispitanika opredijelilo se za najnižu vrijednost (5).

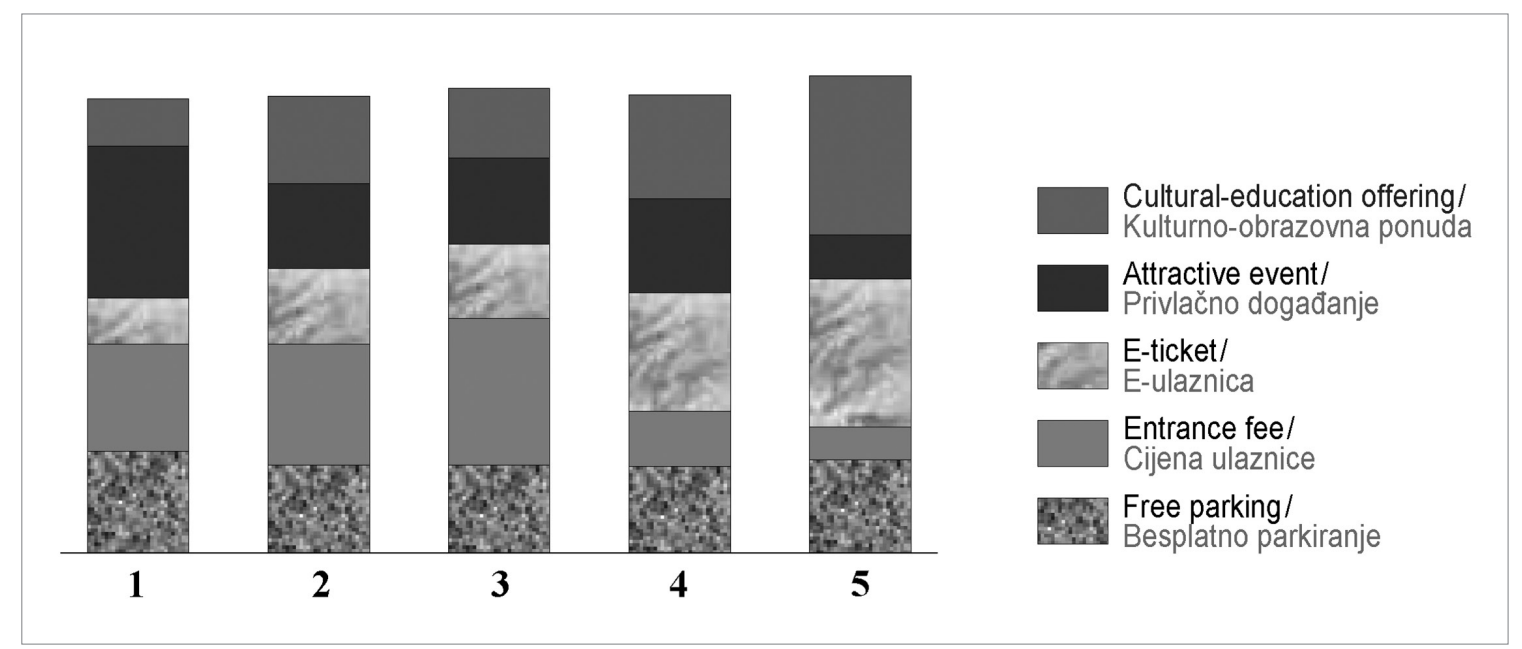

Fig. 4 The importance of the chosen factors to visitors (y axis represents 100\%) SI. 4. Važnost odabranih faktora za posjetitelje ( y os predstavlja $100 \%$ ) 
b) The reason for visiting the researched area.

When asked about the reasons for which they chose to visit lake lands, $28 \%$ of the respondents selected going for a walk, while another quarter of the respondents chose relaxation, and $19 \%$ of them chose recreation. We also met active sportsmen (17\%), $11 \%$ of whom were nature lovers, while $6 \%$ had come for birdwatching, and $5 \%$ were fishermen.

\section{b) Razlog posjeta istraživanom području}

Upitani zašto posjećuju jezersko područje, posjetitelji su kao razloge naveli šetnju (28 \%), opuštanje (25\%) i rekreaciju (19\%). Upoznali smo i aktivne sportaše (17\%), od kojih su $11 \%$ bili zaljubljenici u prirodu; $6 \%$ ispitanika dolazilo je promatrati ptice, a $5 \%$ bili su ribiči.

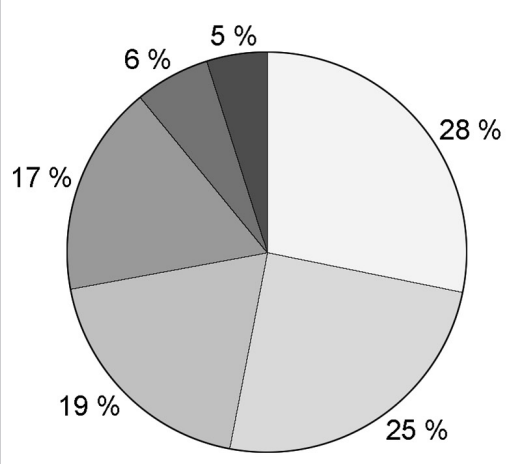

Walking/Šetnja (28 \%)

Relaxation/Opuštanje (25\%)

Recreation/Rekreacija (19\%)

Active sports/Aktivno

bavljenje sportom (17\%)

Birdwatching/Promatranje ptica (6\%)

Fishing/Pecanje (5 \%)
Fig. 5 The prevailing motivations of visitors in visiting the lakes

SI. 5. Prevladavajući motiv posjetitelja koji dolaze na jezersko područje

\section{c) The quality of signs and maintenance of recreational trails and the Škale and Velenje Lake area as a whole.}

The respondents were mostly satisfied with markings on recreational trials and with signs in the area. The majority of the respondents (91\%) were sure that the area did not need any additional signs, only $9 \%$ of respondents suggested that the signs should be refurbished.

When asked about the need for renovations, $60 \%$ of the respondents agreed, whereas $40 \%$ of them were satisfied with the present state of the area. The share of respondents willing to invest closely corresponded to the idea of renovating. Many of the respondents (65\%) were willing to invest, but $35 \%$ of them disagreed with ideas for new content and offerings for the lake lands.

\section{d) The types of activities visitors were prepared to support.}

Those who were interested in cooperation were asked to select the activities they would support. They mostly decided for "sport and recreation"

\section{c) Razina kvalitete markacija te održavanja rekreacijskih staza i cjelokupnoga područja oko Škalskog i Veleniskog jezera}

Ispitanici su uglavnom bili zadovoljni oznakama na rekreacijskim stazama i markacijama na proučavanom području. Većina ispitanika (91 \%) smatrala je da područje ne treba dodatne oznake, a samo $9 \%$ predložilo je obnovu postojećih markacija.

Upitani o potrebi uređenja, $60 \%$ ispitanika složilo se s prijedlogom, a $40 \%$ bilo je zadovoljno trenutačnim stanjem područja. Postotak ispitanika spremnih na ulaganje gotovo je zrcalio stavove o preuređenju, pa je tako $65 \%$ anketiranih bilo voljno uložiti novac, ali njih $35 \%$ nije se složilo s idejama novih sadržaja i ponude jezerskoga područja.

\section{d) Tip aktivnosti koje su posjetiteli spremni podržati}

Ispitanike koji su bili voljni surađivati zamolili smo da navedu aktivnosti koje bi podržali. Većina ih se odlučila za sport i rekreaciju (63\%), što su također 
(63\%), which happens to be the leading current use of the lake area. But $28 \%$ of the respondents thought that inclusion of "culture and education", as new and fresh ideas, could increase the attractiveness of the researched landscape and could bring some new commercial initiative. Both activities were supported by $9 \%$ of the respondents. aktivnosti na koje otpada najveći postotak trenutačnoga načina korištenja zemljišta u jezerskom području. Međutim, $28 \%$ posjetitelja smatralo je da bi uvođenje kulturnih i obrazovni sadržaja kao novih i svježih zamisli moglo povećati privlačnost istraživanoga pejzaža i potaknuti nove komercijalne inicijative, a $9 \%$ ispitanika odabralo je obje aktionosti.

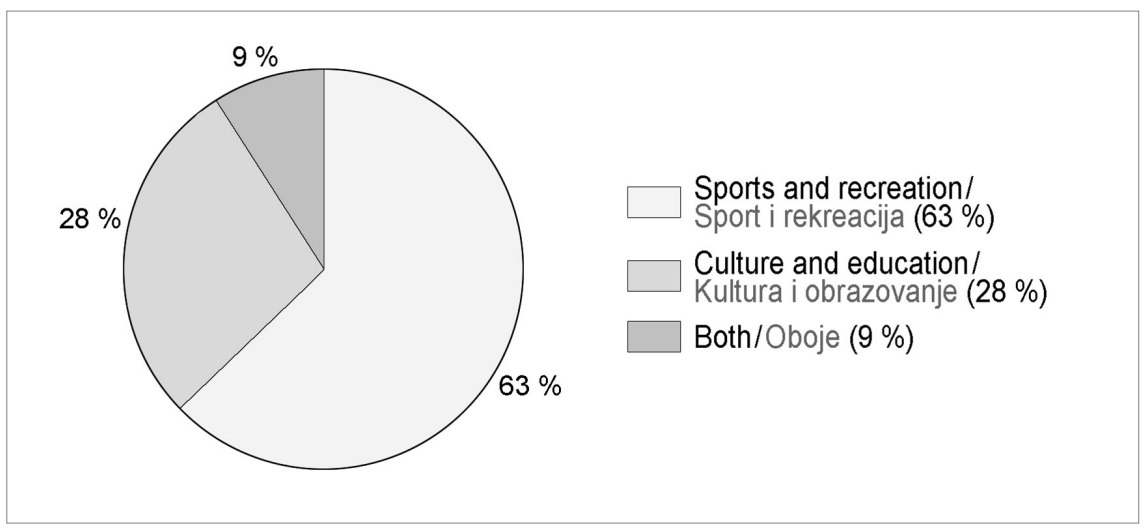

Fig. 6 The suggested activities that respondents would support in the future

SI. 6. Predložene aktivnost koje bi ispitanici podržali u budućnosti

\section{e) Willingness of respondents to pay for the potentially-offered events.}

Quite a few of the respondents (41\%) were prepared to pay up to $€ 5$, another $35 \%$ of them were willing to pay $€ 6-10$, and $15 \%$ of them would support new offerings/events in lake lands with €1120. The highest contribution fee (€20) was chosen by $9 \%$ of the respondents.

\section{e) Spremnost posjetitelia da plate za ponuđene događaje}

Najviše ispitanika, njih $41 \%$, platilo bi do 5 eura, $35 \%$ bi platilo između 6 i 10 eura, a $15 \%$ njih bi podržalo nove ponude/zbivanja na jezerskom području s 11 do 20 eura. Najvišu ulaznicu (20 eura) bilo je spremno platiti $9 \%$ ispitanika.
The Spatial

Development Potential of Škale and Velenje Lakes

Potencijal prostornoga razvoja Škalskog $i$ Velenjskog jezera

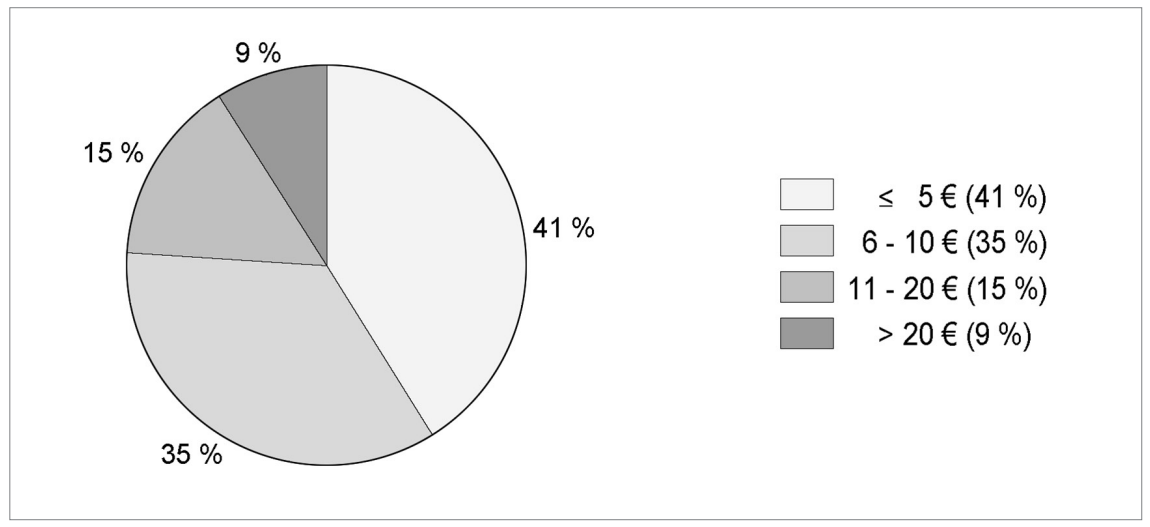

Fig. 7 How much the respondents were prepared to pay for new activities.

SI. 7. Koliko bi posjetitelii platili za nove aktivnosti? 
HRVATSKI

GEOGRAFSKI

GLASNIK

78/2,121-142 (2016.) f) Interest in the availability of a permanent ticket for the newly-offered activities

When asked for their potential interest in a kind of a permanent ticket for potential new activities in lake lands, $35 \%$ of the respondents showed interest, $31 \%$ of them were uninterested, and $34 \%$ of the respondents were undecided.

An attempt to build upon current landscape planning - design of two extreme scenarios of development

The models were designed on the basis of the analysis of attractiveness and the created land use scheme. They were the starting point for further reflection on the development potential of the area of both lakes. However, since these models were based on the initiatives of potential users, we wanted to go further and created two development scenarios. Students were familiarised with the results of the landscape mapping, area attractiveness values, and public opinion survey. They got to know the basic principles of spatial planning in teams, taking risks and compromising during the conception of the two development models for the lakes. They established two extreme scenarios: a) retention and b) intensive development (Fig. 8)

\section{f) Zanimanje za kupnju trajne ulaznice za uporabu novih sadržaja}

Provjeravajući zanimanje posjetitelja za kupnju trajne ulaznice za potencijalne nove aktivnosti na jezerskom području, pokazalo se da se $35 \%$ ispitanika slaže s tom zamisli; $31 \%$ nije bilo zainteresirano, dok je preostalih $34 \%$ bilo neodlučno.

Pokušaj doprinosa planiranju pejzaža oblikovanje dvaju ekstremnih scenarija razvoja

Modeli su osmišljeni na temelju analize privlačnosti i nacrta načina korištenja zemljišta, a bili su i polazište za buduća razmišljanja o razvojnom potencijalu područja obaju jezera. Međutim, budući da su ti modeli nastali prema inicijativama potencijalnih korisnika, cilj nam je bio nadići taj vid, pa smo načinili dva razvojna scenarija. Studenti su bili upoznati s rezultatima pejzažnoga kartiranja, privlačnošću područja i rezultatima anketnoga istraživanja. Zajedničkim su se radom upoznali s osnovnim načelima prostornoga uređenja, riskiranjem i kompromisima pri osmišljavanju dvaju razvojnih modela za dva jezera. Naposljetku su izradili dva ekstremna scenarija: a) zadržavanje postojećega stanja (retencija) i b) intenzivan razvoj (sl. 8.).

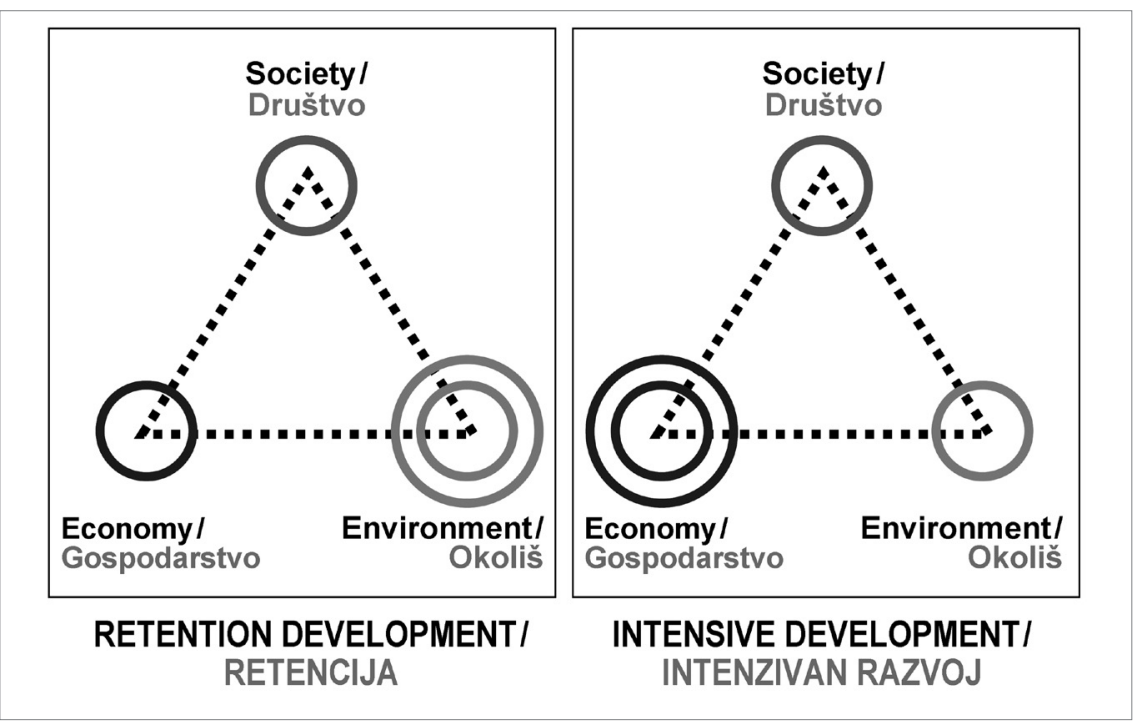

Fig. 8 The balance of the retention and intensive development concepts, regarding the three sustainable pillars leconomy, society, area environment).

SI. 8. Uravnoteženost razvojnih koncepata s obzirom na tri održiva stupa Igospodarstvo, društvo, područje/okoliš): retencija i intenzivni razvoj 
The retention development model would preserve the quality of the existing space as much as possible, and also promote natural development of new activities and their positioning in the lake area. The intensive development model would, irrespective of possible negative effects on the environment, follow the interests of attractiveness and profit.

First, we defined the following: a) the concept of developmental restraint (environmental protection); and b) the concept of intensity (developing economies). We made a somewhat simplified analysis of the space, gathered an analysis of land use, and made an inventory of existing activities. Second, the simulation models for possible actions of retention and intensive development were created, without considering possible locations or their actual feasibility. This was followed by an assessment of both the advantages and the disadvantages of implementing each activity in the area of both lakes. That was the basis used to construct a concrete development plan in the form of a simple spatial zoning of different uses and activities.

The model of retention proposed maintaining the existing sustainable organisation, abolishing the existing arrangement that potentially threatens the environment, and introducing new environmentally friendly activities (e.g. an organic farm for food self-supply).

The model of intensive development anticipated a number of new activities that were particularly appealing and were thus profitable (water theatre, water park, adventure park) and moved for the elimination of the activities which represented only costs (non-profit and/or maintenance expenditures), or barriers for development.

Finally, the students carried out a debate. They simulated a public debate with a presentation and then discussed the advantages and disadvantages of the two development model concepts, one against the other. The outcome of the debate was clear: use of space can only be a compromise between the development and protection of landscape, the balance and consistency in the development of society, economy, and space. We confirmed the hypothesis that extreme scenarios of development were unacceptable for the studied area.
Prvi razvojni model trebao bi što je više moguće zadržati kvalitetu postojećega prostora te poticati prirodni razvoj novih aktivnosti koje bi se postupno uvodile u jezersko područje. S druge strane, model intenzivnoga razvoja trebao bi se, neovisno o mogućim negativnim posljedicama na okoliš, podrediti interesima privlačnosti i profitabilnosti.

Prvo smo definirali sljedeće: a) koncept razvojnih ograničenja (zaštitu okoliša) i b) koncept intenziteta (ekonomiju razvoja). Izradili smo ponešto pojednostavljenu analizu prostora i prikupili analizu načina korištenja zemljišta te sastavili inventar postojećih aktivnosti. Zatim su načinjeni simulacijski modeli mogućih djelovanja u slučaju zadržavanja postojećega stanja i intenzivnoga razvoja, bez razmatranja mogućih lokacija i njihove stvarne izvedivosti. Uslijedila je procjena nedostataka i prednosti primjene svake aktivnosti na području obaju jezera, što je bio temelj za izradu konkretnoga razvojnog plana u obliku jednostavnoga prostornog zoniranja različitih uporaba i aktivnosti.

Model očuvanoga razvoja predložio je zadržavanje postojećega održivog ustroja, ukidanje postojećega rješenja koje potencijalno prijeti okolišu i uvođenje novih, ekološki prihvatljivih aktivnosti (primjerice, poljoprivrednoga gospodarstva za uzgoj organske hrane za lokalne potrebe).

Model intenzivnoga razvoja predvidio je niz novih aktivnosti osobito privlačnih velikom broju ljudi, što ih čini financijski unosnima (kazalište na vodi, vodeni park, pustolovni park) i izbacivanje aktivnosti koje su samo trošak (neprofitnih i/ili onih koje zahtijevaju trošak održavanja), odnosno prepreka za razvoj.

Naposljetku su studenti proveli raspravu tako što su simulirali javnu raspravu na kojoj su predstavljene i sučeljene prednosti i nedostaci dvaju razvojnih modela. Ishod rasprave bio je jasan korištenje prostora može biti samo kompromis između razvoja i zaštite pejzaža, ravnoteže i dosljednosti u razvoju društva, gospodarstva i prostora. Drugim riječima, potvrdili smo hipotezu da su ekstremni scenariji razvoja u tom području neprihvatljivi.
The Spatial

Development Potential of Škale and Velenje Lakes

Potencijal prostornoga razvoja Škalskog $i$ Velenjskog jezera 


\section{Discussion}

"These days, computer graphics are playing an important role in giving lifelike information for the estimation of landscapes after finishing large-scale construction projects. However, how to create vivid photo-realistic images based on exact geometry and optical phenomena is still an essential issue" (Nakamae and Tadamura, 2001, 19).

Daniel, T. C. (2001) found ecosystem management, in terms of spatial reformation and (anthropogenic) changes of landscape, to be a crucial activity of the $21^{\text {st }}$ century. He also highlighted permanent GIS technological upgrades as a very appropriate tool when considering landscape simulation modelling as support for planning new activities/objects in a given area. Bearing in mind the further uses and benefits of the mapped data (municipality spatial plans), we prepared a land use map with proper characteristics according to the field inventory (Fig. 3).

The survey showed that the area researched presented an attractive landscape that people enjoy and have a desire to continue enjoying. Despite the severe environmental burdens of the past, the ecosystem's condition has improved and the surroundings of both lakes have managed to attract both local and non-local visitors. An integrated assessment of the lakes' scenery showed that the main challenge for spatial planners should be to manage the state of the environment in a sustainable fashion. Respondents were also prepared to contribute financially. Their prevailing investment motivations were in "sport and recreation" (63\% of respondents); $28 \%$ would pay rather for the 'cultural and educational' activities; 9\% supported any/all activities.

The inventory of land use information was essential for the introduction to scenario method. The fieldwork mapping was upgraded into a digitalisation of the land cover of the researched area with the help of ArcView software. Students gained skills in planning new activities in a given landscape, along with learning how to deal with having their ideas confronted and how to make compromises. The suggested development scenarios, retention and intensive, included "pro" and "contra" arguments, considering their sustainable development characteristics; in addition, they were prepared visually.

\section{Diskusija}

„Računalna grafika danas ima važnu ulogu u davanju stvarnih informacija za procjenu pejzaža nakon dovršetka opsežnih građevinskih projekata. Međutim, i dalje je iznimno važno pitanje kako stvoriti žive, fotorealistične slike temeljene na točnoj geometriji i optičkim pojavama" (Nakamae i Tadamura, 2001, 19).

T. C. Daniel (2001) je upravljanje ekosustavom kad je riječ o prostornom preoblikovanju i (antropogenim) promjenama pejzaža ocijenio ključnom aktivnošću u 21. stoljeću. Također je istaknuo trajno tehnološko unapređivanje geografskoga informacijskog sustava kao vrlo prikladan alat za razmatranje modeliranja simulacije pejzaža kao podršku za planiranje novih aktivnosti/objekata u odabranom području. Imajući na umu daljnju uporabu i koristi kartiranih podataka (općinski prostorni planovi), pripremili smo kartu načina korištenja zemljišta s odgovarajućim značajkama prema terenskom inventaru (Sl.3).

Anketno istraživanje pokazalo je da područje o kojem je riječ karakterizira privlačan pejzaž u kojem njegovi posjetitelji dolaze uživati, a željeli bi to nastaviti i ubuduće. Unatoč velikom ekološkom teretu iz prošlosti ekosustav se oporavio i obale obaju jezera privlače brojne posjetitelje: one koji žive u blizini, ali i posjetitelje iz drugih krajeva. Integrirana procjena jezerskoga pejzaža pokazala je da bi glavni izazov za prostorne planere trebalo biti očuvanje stanja okoliša na održiv način. Ispitanici su također bili voljni financijski pridonijeti projektu, a najviše su htjeli uložiti u sport i rekreaciju (63\% anketiranih posjetitelja), $28 \%$ platilo bi radije za kulturne i obrazovne aktivnosti, a 9 $\%$ ih je podržalo sve predložene aktivnosti.

Inventar informacija o načinu korištenja zemljišta bio je od presudne važnosti za uvod u metodu scenarija. Terensko kartiranje je s pomoću softvera ArcView unaprijeđeno u digitalizaciju zemljišnoga pokrova istraživanog područja. Studenti su razvili vještine planiranja novih aktivnosti u određenom pejzažu, preispitivanja svojih zamisli i činjenja kompromisa. Predloženi scenariji razvoja, retencija ili zadržavanje postojećeg stanja i intenzivni razvoj, uključili su argumente $z a$ i protiv uzimajući u obzir značajke održivoga razvoja. Pritom su scenariji vizualno dobro pripremljeni. 


\section{Conclusion}

The planned policies should be based on the inclusion of all stakeholders interested in the use of the lake area and its surroundings as resources; in addition to the users' role in the process of planning, the role of decision makers and spatial planners (who must be aware of limitations of the environment in which they are planning) are both key.

The results were meant to help planners with the placement of future activities and different services (infrastructure, services, and offerings) in the space surrounding the lakes - that was evaluated with high values of landscape aesthetic quality by locals and non-locals, who were indirectly introduced to the researched area. The database for future planning was prepared using GIS tools.

The lake area and the evaluation of its visual aesthetic qualities showed a high level of landscape attraction potential. Almost half of the respondents (48.9\%) in 2013 rated the lake lands as very attractive (value "high"). In 2014, 41.5\% of the visitors also gave the lake lands a "high" rating for attractiveness. We assumed the discussed landscape to be very promising after first consequences of underground degradation from lignite excavation turned into development potential for the flooded (lake) area.

Respondents were also aware of this phenomenon. They mostly saw the lake lands as a "large" scale (92.8\%), "diversified" (62.8\%), "balanced" (66.7\%) and "peaceful" (71.4\%) area; "bright" (42.9\%) in regard to colours and "neutral" in smell (61.3\%); with "still" sound ratings (67.4\%). Positive, pleasant impressions and feelings were prevalent.

The data also showed that the frequency with which people visited the lakes testified to their potential. Once or twice per month Škale Lake was visited by $39 \%$ of the respondents and Velenje Lake by $47 \%$ of them. The remainder of the respondents enjoyed the lake landscape weekly or even daily.

Landscape planning is already apparent from the pre-designed models of attractiveness and vulnerability. Their synthesis shows what the conditions needed for the development of an individual activity are and what is favourable for the space.

\section{Zaključak}

Planske mjere trebale bi se temeljiti na uključivanju svih dionika zainteresiranih za korištenje jezerā i njihova okruženja kao resursa. Uz sudjelovanje korisnika (odnosno posjetitelja područja) ključnu ulogu u procesu planiranja imaju donositelji odluka i prostorni planeri koji moraju biti svjesni ograničenja okoliša u kojem se planiraju zahvati.

Rezultati su trebali pomoći pri planiranju budućih aktivnosti i različitih elemenata (infrastrukture, usluga, opskrbe) na području oko dvaju jezera koje su estetski iznimno kvalitetnim procijenili i lokalni stanovnici i stranci koji su neizravno upoznati s proučavanim područjem. Baza podataka za buduća prostorna planiranja pripremljena je uporabom GIS alata.

Jezersko područje i procjena njegove vizualne i estetske kvalitete pokazali su visoku razinu potencijala privlačnosti pejzaža. Gotovo polovica (48,9 \%) ispitanika ocijenila je 2013. godine jezersko područje vrlo privlačnim (vrijednost „visoka”). Godinu dana poslije $41,5 \%$ posjetitelja odlučilo se za kategoriju „visoka”. Istraživani smo pejzaž smatrali vrlo obećavajućim nakon što su se prve degradacijske posljedice podzemnoga iskapanja lignita pretvorile u razvojni potencijal poplavljenoga (jezerskog) područja.

Ispitanici su također bili svjesni te činjenice i uglavnom su jezersko zemljište smatrali velikim $(92,8 \%)$, raznovrsnim $(62,8 \%)$, uravnoteženim $(66,7 \%)$ i spokojnim $(71,4 \%)$ područjem, svijetlim $(42,9 \%)$ kad je riječ o bojama i neutralnim glede mirisa $(61,3 \%)$ te tihim $(67,4 \%)$. Ukratko, prevladavali su pozitivni, ugodni dojmovi i osjećaji.

Podaci o učestalosti posjeta jezerima potvrdili su i potencijal jezerskoga zemljišta. Jednom ili dvaput mjesečno Škalsko jezero posjetilo bi $39 \%$ ispitanika, a Velenjsko jezero 47 \%. Ostatak posjetitelja uživao je u jezerima na tjednoj ili čak dnevnoj bazi.

Pejzažno planiranje vidljivo je već iz prethodno dizajniranih modela privlačnosti i osjetljivosti, a njihova sinteza pokazuje koji su uvjeti potrebni za razvoj pojedinačne aktivnosti i što je prikladno za prostor.
The Spatial

Development Potential of Škale and Velenje Lakes

Potencijal prostornoga razvoja Škalskog $i$ Velenjskog jezera 
Consideration of how planned activities will change a space should serve as a guideline. Answering this question may provide the only real basis for deciding which activities are permissible in the area plan (Marušič, 2015).

Providing a balance of the triangle "environment-economy-society" should be the foundation of any responsible planning endeavour. At the time of former Yugoslavia (SFRY) both the Law on social planning (SFRY Official Gazette, 46/85; Official Gazette, 1/80, 33/80, 2/81) and Slovenian spatial legislation were based upon it as a compulsory, formally-established approach.

Amendments to the legislation have not ensured that continuity. European development guidelines have encouraged the introduction of integrated planning, which is essentially the same as former (pre-1991) social planning. Due to the previous method of planning, the current image of the subsidence area of Šalek valley lake lands is solid. Whether it will remain as such is highly dependent on future decision making. Knowledge, tolerance, good planning and compromise should prevail over ignorance, intolerance, poor planning and capital.

The following findings and characteristics of the area might prove useful:

a) The current extensive arrangements might be preferable in maintaining sustainable equilibrium in the lake lands (visibility, usability, and satisfactory visits of both lake areas were recorded);

b) A comprehensive plan for the area is required and not only for partial placement of activities (a wealth of local experience and knowledge of the spatial disciplines are available);

c) Despite the respondents' given opinions, there is a possibility for fundamental policies that would follow a sustainable (self-conservation) approach; involving positioning a variety of soft activities, events, and sustainable interventions/ arrangements where necessary;

d) History, industrial heritage, and the phenomenon of environmental remediation;

e) Future land use is a key decision for target
Razmatranje pitanja promjene prostora zbog planiranih aktivnosti trebala bi biti misao vodilja. Samo bi odgovor na to potonje (Marušič, 2015) mogao biti stvaran temelj za donošenje odluke o tome koje su aktivnosti dopustive u planu budućega izgleda prostora.

Postizanje ravnoteže trokuta okoliš-gospodarstvo-društvo trebalo bi biti temelj svakoga odgovornog planiranja prostora. U vrijeme bivše Jugoslavije (SFRJ) Zakon o društvenom planiranju (SFRY Official Gazette, 46/85; Official Gazette, 1/80, $33 / 80,2 / 81$ ) i slovenski propisi o prostornom uređenju temeljeni su na toj ravnoteži kao obveznom i formalno uspostavljenom pristupu.

Međutim, dopune i izmjene zakona nisu zajamčile taj kontinuitet. Europske razvojne smjernice potaknule su uvođenje integriranoga planiranja koje je u osnovi ostalo isto kao i prijašnje društveno planiranje (prije 1991.). Zbog prijašnjih metoda planiranja trenutačna predodžba o subsidencijskom području Šaleške doline vrlo je čvrsta. Međutim, hoće li takva i ostati, uvelike ovisi o budućim odlukama. Znanje, tolerancija, planiranje i kompromis trebali bi nadvladati neznanje, netolerantnost, nekvalitetno planiranje i kapital.

Ovi zaključci i značajke područja mogli bi biti od pomoći:

a) prednost bi se mogla dati i postojećem opsežnom rješenju da bi se jezersko područje zadržalo u stanju održive ravnoteže (zabilježeni su vidljivost, iskoristivost i zadovoljstvo posjetom obama jezerskim područjima)

b) potreban je sveobuhvatan plan za cijelo područje, a ne samo djelomično pozicioniranje aktivnosti (na raspolaganju je bogato lokalno iskustvo i poznavanje prostornoga uređenja)

c) unatoč prikupljenim mišljenjima ispitanika postoji mogućnost temeljite promjene koja bi zadovoljila smjernice održivoga razvoja (samoočuvanje); pozicioniranje raznovrsnih mirnijih aktivnosti, događaja i održivih intervencija/ uređenja gdje su potrebni

d) povijest, industrijsko nasljeđe i fenomen okolišne remedijacije

e) kad je riječ o okolišnom kapacitetu i prostornim 
groups, as is the direction/level of planned commercialisation regarding the environmental capacity and space limitations (e.g. biological and chemical parameters of the state of environmental resources such as water and soil).

Professional Terms Editing: Petra Radeljak Kaufmann, $\mathrm{PhD}$, Postdoctoral Fellow

The first-year students of the Environmental Protection College generation 2014-2015 were introduced to this fieldwork for the subject of Evaluation and Protection of the Geographical Environment. They carried out the mapping and the survey on landscape potentials of Škale Lake. The students of the International Summer School University of Oslo 2014 were also involved in the landscape quality assessment. Later on, this topic was discussed within the study subjects Spatial Planning and Environmental Communication. ograničenjima (primjerice biološki i kemijski parametri stanja resursa poput vode i tla), budući način korištenja zemljišta ključna je odluka za ciljane skupine i smjer, odnosno razinu planirane komercijalizacije.

Stručna redaktura: dr. sc. Petra Radeljak Kaufmann, poslijedoktorandica

Studenti prve godine Visoke škole za zaštitu okoliša generacije 2014./2015. upoznati su s terenskim radom u sklopu kolegija Vrednovanje i zaštita geografskog okoliša te su proveli kartiranje i anketno istraživanje o pejzažnom potencijalu Škalskog jezera. Studenti Međunarodne ljetne škole Sveučilišta u Oslu 2014. također su bili uključeni u procjenu kakvoće pejzaža. Poslije se o toj temi raspravljalo u sklopu kolegija Prostorno planiranje i Komunikacija okolišnih pitanja.
Atlas okolja, http://gis.arso.gov.si/atlasokolja/profile.aspx?id=Atlas_Okolja_AXL@ Arso (5.12.2015.)

Daniel, T. C., 2001: Whither scenic beauty? Visual landscape quality assessment in the 21st century. Landscape and Urban Planning 54 (1-4), 267-281.

ESPON, 2014: European Union: ESPON 2020 Programme, http://www.espon.

eu/main/Menu_Programme/Menu_ESPON2020Programme/index.html, 16. 2. 2014

EUROPE 2020, 2010: European Commission: Europe 2020 Strategy, http://ec.europa.eu/europe2020/ (21.2.2014.)

Forman, R. T. T, Godron, M., 1986: Landscape Ecology, Wiley, New York.

INSPIRE, 2014: European Commission: Infrastructure for Spatial Information in the

European Communit, http://inspire.jrc. ec.europa.eu/ (7.2.2014.)

Kliučininkas, L., 2008: Environmental Aspects of Brownfield Redevelopment, Department for Environmental Engineering. Kaunas University of Technology, Lithuania. http://fast10.vsb.cz/bribast
The Law on the foundations of the system of social planning and social plan of Yugoslavia, SFRY Official Gazette, 46/85 (Law is not current).

The Law on the foundations of the system of social planning and social plan of $S R$ Slovenia, Official Gazette, 1/80, 33/80, $2 / 81$ (Law is not current).

Marušič, I., 2007: Krajinsko planiranje v dobi globalizacije, prispevek v zborniku mednarodnega posveta, Portorož, p. 9-10.

Marušič, I., 1986: Metode v krajinskem planiranju, pregled s komentarjem, Skripta, Ljubljana.

Marušič, I., 2015: Jutranja zarja ali somrak - Stanje krajinskega planiranja v Sloveni$j i$, predavanje na skupščini DKAS, November 2015.

Nakamae, E., Qin, X., Tadamura, K., 2001: Rendering of landscapes for environmental assessment, Landscape and Urban Planning 54 (1-4), 19-32.

Piano, S., 1994: Krajinske zasnove območja ugrezninskega polja, 4. faza, 1. del; št. proj. 843/94-KZ-SP, Zavod za urbanizem Velenje, Velenje.
Piano, S., 1995: Krajinske zasnove območja ugrezninskega polja, 4. faza, 2. del; št. proj. 843/95-KZ-SP, Velenje, Zavod za urbanizem, Velenje.

Piano, S., Gojević, G., Dolenec Gojević, A., 2011: Urbanistična zasnova Šoštanja - analitični del; št. projekta $\mathrm{Pi}_{-}$ ano/11/2001-UZ-SP, PIANO, Atelje krajinske arhitekture, Velenje.

Piano, S., Gojević, G., Dolenec Gojević, A., 2002: Urbanistična zasnova Šsoštanja - zasnova razvoja in programska zasnova; št. projekta Piano/11/2001-UZ, PIANO, Atelje krajinske arhitekture, Velenje.

Piano, S. et al., 2013: Strokovne podlage za ureditev območja Družmirskega jezera, Idejna zasnova strokovnih podlag, št. projekta AREA ARS/42/2011-OPPN-SP(IDZ); nosilec naloge, AREA ARS d.o.o., Velenje.

Spatial Planning Act, Official Gazette, $33 / 07$ and further (the law is valid).

Špeh, N., Furlan, L., 2015: Razvojni prostorski potencial Škalskega in Velenjskega jezera: poročilo o terenskem delu projekta [COBISS.SI-ID 13414039], Visoka šola za varstvo okolja, Velenje.
The Spatial

Development

Potential of Škale and Velenje Lakes

Potencijal

prostornoga

razvoja Škalskog $i$

Velenjskog jezera

Zahvala

Acknowledgement

Literature

Literatura 


\section{GEOGRAFSKI}

GLASNIK

78/2,121-142 (2016.)
Šterbenk, E., Pavšek, Z., Al Sayegh-Petkovšek, S., Mazej, Z., Kugonič, N., Poličnik, H., Pokorny, B., Ramšak, R., Rošer-Drev, A., Mljač, L., Bole, M., Glinšek, A., Marko, Druks, M., Gajšek, P., Flis, J., Kotnik, K., Zorko, V., Goltnik, V., Vrhovšek, D., Zupančič Justin, M.,
Urana, D., 2011: Šaleška jezera - vodni vir in razvojni izziv: končno poročilo, ERICo, Velenje.

Zavod za urbanizem Velenje, 1988: Krajinske zasnove območja ugrezninskega polja, 1. faza; št. proj. 644/88-KZ-SP, Velenje.
Zavod za urbanizem Velenje, 1990: Krajinske zasnove območja ugrezninskega polja, 2. faza; št. proj. 843/89-KZ-SP, Velenje.

Zavod za urbanizem Velenje, 1990: Krajinske zasnove območja ugrezninskega polja, 3. faza; št. proj. 843/90-KZ-SP, Velenje.
Authors

Autori
Natalija Špeh natalija.speh@vsvo.si

Assistant Professor, Environmental Protection College Velenje, Trg mladosti 7 , 3320 Velenje, Slovenia

Saša Piano

atelje.piano@t-2.si

Environmental Protection College Velenje/Atelje Piano, Koroška 11,

3320 Velenje, Slovenia 